\title{
Het Erfolgsort bij zuivere vermogensschade: een poging tot plaatsbepaling van een moving target
}

\author{
Mr. B.F.L.M. Schim, mr. D.J. Verbeijen \\ $m r . F . E . \quad V e r m e u l e n^{*}$
}

\begin{abstract}
1 Inleiding
Een onrechtmatige daad kan grensoverschrijdend worden gepleegd en in verschillende landen schade veroorzaken. Het is vaste rechtspraak van het Hof van Justitie van de EU (hierna: Hof) sinds het arrest Bier ${ }^{1}$ dat indien de plaats van de handeling die de schade heeft veroorzaakt en de plaats van het intreden van de schade uiteenlopen, art. 7 punt 2 van de Brussel I bis-Verordening (hierna: Brussel I bis-Vo) ${ }^{2}$ rechtsmacht verleent aan zowel de rechter van de plaats waar de schade is ingetreden als de rechter van de plaats van de handeling. De eiser kan de verweerder dan voor het gerecht van de ene dan wel van de andere plaats dagen. Dit is een uitzondering op de hoofdregel dat de rechter van de woonplaats van de gedaagde internationaal bevoegd is (art. 4 Brussel I bis-Vo). De uitzonderingsregel voor verbintenissen uit onrechtmatige daad heeft geleid tot veel rechtspraak over verschillende schadetypen, zoals schade aan gewassen door zoutlozing in een rivier, schade aan reputatie en goede naam, schade door een inbreuk op IErechten en zuivere vermogensschade. ${ }^{3}$ De laatste categorie schade heeft de laatste jaren in het bijzonder de gemoederen beziggehouden ${ }^{4}$ en is aanleiding geweest voor verschillende
\end{abstract}

Mr. B.F.L.M. Schim is advocaat bij NautaDutilh te Amsterdam. Mr. D.J. Verheij is advocaat bij NautaDutilh te Amsterdam. Mr. F.E. Vermeulen is advocaat bij NautaDutilh te Amsterdam.

1. HvJ EU 30 november 1976, C-21/76, ECLI:EU:C:1976:166 (Handelskwekerij Bier/Mines de Potasse d'Alsace).

2. Verordening 1215/2012 van het Europees Parlement en de Raad van 12 december 2012 betreffende de rechterlijke bevoegdheid, de erkenning en de tenuitvoerlegging van beslissingen in burgerlijke en handelszaken.

3. Zie voor een rubricering M.H. ten Wolde, De plaats van het Erfolgsort in het forum delicti van het EEX. Is de puzzel gelegd?, NIPR 2020, afl. 2, p. 251 e.v.

4. Zie bijv. voorafgaand aan VEB/BP L.M. van Bochove, Money's too tight to mention. De problematische vaststelling van het Erfolgsort bij zuivere vermogensschade, Ondernemingsrecht 2021/38 en Ten Wolde 2020, p. 251 e.v., en naar aanleiding van VEB/BP A.Ch.H. Franken, Hof van Justitie EU 12 mei 2021, ECLI:EU:C:2021:377 (VEB/BP plc). Bevoegdheid rechter bij corporate misinformation, Bb 2021/65, W.A.K. Rank, Locatie rekening niet bepalend voor schadeclaims, Financial Investigator 2021, afl. 4, p. 78 en L.M. van Bochove \& M. Haentjens, Effectenbezitters: New Efforts to Localise the Place of Damage, EAPIL Blog 23 juni 2021, https://eapil.org/2021/06/23/effectenbezitters-answersbut-also-more-questions/. uitspraken, met name de arresten Kronhofer/Maier, Kolassa/ Barclays, Universal Music Holding en Löber/Barclays. ${ }^{5}$ Het arrest $\mathrm{VEB} / \mathrm{BP}$ voegt een nieuwe loot toe aan deze rechtspraak over zuivere vermogensschade. Aangezien wij verwachten dat het Hof zal blijven vasthouden aan het Erfolgsort bij zuivere vermogensschade, vormt dit arrest aanleiding om de rechtspraak van het Hof over het Erfolgsort te bespreken vanuit de invalshoek van de grondslagen van art. 7 punt 2 Brussel I bisVo. Daarbij zullen wij ook stilstaan bij de vraag hoe VEB/BP past in de eerdere lijn van de rechtspraak van het Hof.

\section{De uitspraak in VEB/BP}

\subsection{Casus en procesverloop}

In de zaak VEB/BP heeft de Vereniging van Effectenbezitters (hierna: VEB) een collectieve actie ingesteld tegen het olie- en gasbedrijf BP. De VEB stelde de collectieve actie in namens (oud-)aandeelhouders van BP naar aanleiding van een explosie op het olieboorplatform Deepwater Horizon in 2010. De BPaandeelhouders verwijten BP onder meer dat zij onjuiste, onvolledige en misleidende mededelingen heeft gedaan over (1) haar veiligheids- en onderhoudsprogramma's vóór de olieramp in 2010, (2) de omvang van deze olieramp en (3) de rol en verantwoordelijkheid van BP bij deze olieramp. De achterban van de VEB wordt gevormd door personen die in een afgebakende periode voor de explosie gewone BP-aandelen hadden gekocht, gehouden of verkocht via een in Nederland aangehouden beleggingsrekening of een beleggingsrekening van een in Nederland gevestigde bank en/of beleggingsonderneming. ${ }^{6}$ De hamvraag is of de Nederlandse rechter rechtsmacht heeft om de vorderingen van de VEB te beoordelen.

5. HvJ EU 10 juni 2004, C-168/02, ECLI:EU:C:2004:364 (Kronhofer/ Maier), HvJ EU 28 januari 2015, C- 375/13, ECLI:EU:C:2015:37 (Kolassa/Barclays Bank), HvJ EU 16 juni 2016, C-12/15, ECLI:EU:C: 2016:449 (Universal Music) en HvJ EU 12 september 2018, C-304/17, ECLI:EU:C:2018:701 (Löber/Barclays Bank).

6. HvJ EU 12 mei 2021, C-709/19, ECLI:EU:C:2021:377 (VEB/BP), punten 7 en 9-11. 
Hierbij zijn de volgende omstandigheden relevant: BP is gevestigd in Londen, de explosie heeft plaatsgevonden in de Golf van Mexico, de gewone aandelen van BP zijn genoteerd aan de beurzen van Londen en Frankfurt, er zijn American Depository Receipts genoteerd aan de beurs van New York, de betreffende aandeelhouders hebben de BP-aandelen gekocht, gehouden of verkocht via een in Nederland aangehouden beleggingsrekening, en de grondslag van de vordering is onrechtmatige daad wegens onjuiste, onvolledige en misleidende mededelingen. ${ }^{8}$

De VEB en BP verschilden van inzicht over de vraag of de Nederlandse rechter rechtsmacht kan aannemen op grond van art. 7 lid 2 Brussel I bis-Vo en, meer in het bijzonder, of het Erfolgsort van de door de BP-aandeelhouders geclaimde schade in Nederland ligt. De VEB lokaliseerde het Erfolgsort in Nederland, nu de BP-aandeelhouders daar de beleggingsrekeningen aanhielden waarop de aandelen waren geadministreerd. ${ }^{9}$ BP bestreed dit standpunt onder verwijzing naar onder meer het arrest Universal Music. ${ }^{10}$ De rechtbank Amsterdam stelde BP in het gelijk en verklaarde zich onbevoegd, waarna het gerechtshof Amsterdam dit vonnis bekrachtigde. ${ }^{11}$

In de cassatieprocedure werden vervolgens prejudiciële vragen aan het Hof gesteld. De Hoge Raad nam als uitgangspunt dat de schade van de BP-aandeelhouders rechtstreeks op de beleggingsrekeningen is ingetreden, zodat vaststaat dat het in deze zaak om directe schade gaat: ${ }^{12}$

'Partijen hebben in feitelijke instanties gedebatteerd over de vraag of de schade als gevolg van het beweerde onrechtmatige handelen door BP rechtstreeks is ingetreden op de beleggingsrekeningen. Het hof heeft kennelijk veronderstellenderwijs tot uitgangspunt genomen dat de gestelde (zuiver financiële) schade zich rechtstreeks heeft voorgedaan op de in Nederland aangehouden beleggingsrekeningen. Ook in deze cassatieprocedure moet daarvan worden uitgegaan.'

Op basis van deze premisse stelde de Hoge Raad een viertal prejudiciële vragen. De eerste vraag betrof de lokalisering van de zuivere vermogensschade die zou zijn geleden door de BPaandeelhouders. Enigszins verkort weergegeven was de vraag of art. 7 lid 2 Brussel I bis-Vo zo dient te worden uitgelegd:

7. HvJ EU 12 mei 2021, C-709/19, ECLI:EU:C:2021:377 (VEB/BP), punt 8 .

8. HvJ EU 12 mei 2021, C-709/19, ECLI:EU:C:2021:377 (VEB/BP), punten 10-11.

9. Rb. Amsterdam 28 september 2016, ECLI:NL:RBAMS:2016:6593, r.o. 4.7.7.

10. Rb. Amsterdam 28 september 2016, ECLI:NL:RBAMS:2016:6593, r.o. 4.7.8.

11. Hof Amsterdam 7 november 2017, ECLI:NL:GHAMS:2017:4588.

12. HR 14 juni 2019, ECLI:NL:HR:2019:925, r.o. 4.5. 'dat het rechtstreeks intreden van zuiver financiële schade op een in Nederland aangehouden beleggingsrekening of een beleggingsrekening van een in Nederland gevestigde bank of beleggingsonderneming, welke schade het gevolg is van beleggingsbeslissingen genomen onder invloed van algemeen verspreide, maar onjuiste, onvolledige en misleidende informatie van een internationale beursgenoteerde onderneming, een voldoende aanknopingspunt oplevert voor internationale bevoegdheid van de Nederlandse rechter uit hoofde van het (...) [Erfolgsort]'.

Als dat niet het geval zou zijn, dan luidde de vervolgvraag of, en zo ja, welke bijkomende omstandigheden zijn vereist die rechtvaardigen dat de Nederlandse rechter rechtsmacht kan aanvaarden. ${ }^{13}$ De overige drie vragen hadden betrekking op de toepassing van art. 7 lid 2 Brussel I bis-Vo in geval van een collectieve actie op grond van art. 3:305a BW. Meer in het bijzondere luidde de tweede prejudiciële vraag of het antwoord op de eerste prejudiciële vraag anders is, indien het gaat om een vordering die op de voet van art. 3:305a BW is ingesteld. $\mathrm{Nu}$ het Hof de derde en vierde vraag niet inhoudelijk heeft beantwoord, behandelen wij deze vragen hier verder niet.

\subsection{Uitspraak Hof van Justitie}

Het Hof legt de eerste en de tweede door de Hoge Raad gestelde vraag als volgt uit: ${ }^{14}$

'Met zijn eerste en zijn tweede vraag, die gezamenlijk dienen te worden onderzocht, wenst de verwijzende rechter in essentie te vernemen of artikel 7 , punt 2 , van verordening nr. 1215/2012 aldus moet worden uitgelegd dat het feit dat op een beleggingsrekening rechtstreeks zuiver financiële schade ontstaat die het gevolg is van beleggingsbeslissingen die zijn genomen onder invloed van wereldwijd gemakkelijk toegankelijke maar onjuiste, onvolledige en misleidende informatie van een internationale beursgenoteerde vennootschap, het in bepaalde omstandigheden mogelijk maakt om uit hoofde van het intreden van de schade uit te gaan van de internationale bevoegdheid van een rechterlijke instantie van de lidstaat waar de bank of beleggingsonderneming gevestigd is waarbij de rekening in het register is ingeschreven, wanneer die vennootschap niet onderworpen was aan wettelijke openbaarmakingsverplichtingen in die lidstaat.'

Het Hof stelt vervolgens een aantal (inmiddels welbekende) algemene regels uit eerdere uitspraken voorop:

- De bijzondere bevoegdheidsregel uit art. 7 punt 2 Brussel I bis-Vo moet autonoom en restrictief worden uitgelegd. ${ }^{15}$

13. HR 14 juni 2019, ECLI:NL:HR:2019:925, r.o. 6.

14. HvJ EU 12 mei 2021, C-709/19, ECLI:EU:C:2021:377 (VEB/BP), punt 22.

15. HvJ EU 12 mei 2021, C-709/19, ECLI:EU:C:2021:377 (VEB/BP), punt 24. Zie ook o.a. HvJ EU 12 september 2018, C-304/17, ECLI:EU:C:2018:701 (Löber/Barclays Bank), punt 17. 
- Op grond van art. 7 punt 2 Brussel I bis-Vo heeft de eiser de keuze om de gedaagde op te roepen voor de gerechten van zowel de plaats waar de schade is ingetreden (Erfolgs$o r t)$ als de plaats van de gebeurtenis die met de schade in een oorzakelijk verband staat (Handlungsort). ${ }^{16}$

- Het begrip 'de plaats waar het schadebrengende feit zich heeft voorgedaan' mag niet zodanig ruim worden uitgelegd dat zij zich uitstrekt tot elke plaats waar de schadelijke gevolgen voelbaar zijn van een feit dat reeds elders daadwerkelijk ingetreden schade heeft veroorzaakt, en omvat aldus geen indirecte schade. ${ }^{17} \mathrm{Op}$ deze regel, die afkomstig is uit het arrest Marinari, ${ }^{18}$ komen wij hierna nog uitvoeriger terug (zie par. 4).

Daarna gaat het Hof in op zijn eerdere rechtspraak over zuivere vermogensschade. Het Hof herhaalt dat de rechter van de woonplaats van de eiser bevoegd is als die woonplaats daadwerkelijk de plaats is waar de schadebrengende gebeurtenis zich heeft voorgedaan of de schade is ingetreden. Niet kan worden gezegd, aldus het Hof, dat de schade is ingetreden in de woonplaats van de eiser omdat zich daar het centrum van zijn vermogen bevindt, als de schade geleden door de eiser voortvloeit uit het in een andere lidstaat ontstane en door de eiser geleden verlies van onderdelen van zijn vermogen. ${ }^{19}$

Het Hof benadrukt vervolgens waar het in het onderhavige hoofdgeding om gaat: de vaststelling van de plaats waar de schade is ingetreden, waartoe moet worden gekeken naar de plaats waar de beweerde schade zich concreet voordoet. ${ }^{20}$

Het Hof komt tot een beantwoording van de eerste twee prejudiciële vragen door de onderhavige zaak te contrasteren met de zaak Löber/Barclays ${ }^{21}$ (een zaak over prospectusaansprakelijkheid waarin het Erfolgsort werd gelokaliseerd in de woonplaats van de belegger). Het Hof legt zijn uitspraak in Löber/ Barclays zo uit dat de gerechten van de woonplaats van de eiser rechtsmacht kunnen aannemen ten aanzien van een vordering tegen een uitgevende instelling op grond van prospectusaansprakelijkheid en wegens de niet-nakoming van andere op die uitgevende instelling rustende informatieplichten, met name wanneer de beweerde schade zich rechtstreeks voordoet op

16. HvJ EU 12 mei 2021, C-709/19, ECLI:EU:C:2021:377 (VEB/BP), punt 26. Zie ook o.a. HvJ EU 30 november 1976, C-21/76, ECLI:EU:C: 1976:166 (Handelskwekerij Bier/Mines de Potasse d'Alsace), punt 25.

17. HvJ EU 12 mei 2021, C-709/19, ECLI:EU:C:2021:377 (VEB/BP), punt 27.

18. HvJ EU 19 september 1995, C-364/93, ECLI:EU:C:1995:289 (Marinari/Lloyds Bank).

19. HvJ EU 12 mei 2021, C-709/19, ECLI:EU:C:2021:377 (VEB/BP), punten 28-29. Zie ook HvJ EU 10 juni 2004, C-168/02, ECLI:EU:C: 2004:364 (Kronhofer/Maier), punt 21 en HvJ EU 16 juni 2016, C-12/15, ECLI:EU:C:2016:449 (Universal Music), punt 23.

20. HvJ EU 12 mei 2021, C-709/19, ECLI:EU:C:2021:377 (VEB/BP), punten 30-31.

21. HvJ EU 12 september 2018, C-304/17, ECLI:EU:C:2018:701 (Löber/ Barclays Bank). een bankrekening van de eiser 'die wordt aangehouden bij een in het rechtsgebied van die gerechten gevestigde bank'. ${ }^{22}$

Het Hof vindt de rechtvaardiging voor deze benadering in de doelstellingen van de Brussel I bis-Vo: de rechtsbescherming wordt versterkt door: ${ }^{23}$

'zowel de verzoeker in staat te stellen om gemakkelijk te achterhalen welk gerecht hij kan adiëren als ervoor te zorgen dat het voor de verweerder redelijkerwijs voorzienbaar is voor welk gerecht hij kan worden opgeroepen, daar de emittent van een certificaat die zijn wettelijke verplichtingen met betrekking tot de prospectus niet nakomt er, wanneer hij besluit de prospectus voor dit certificaat in andere lidstaten te laten notificeren, rekening mee moet houden dat in die lidstaten woonachtige, onvoldoende geïnformeerde marktdeelnemers beleggen in dat certificaat en schade lijden'.

Als er voor de uitgevende instelling van effecten geen wettelijke openbaarmakingsverplichtingen gelden in de lidstaat waar de beleggingsrekening wordt aangehouden, wordt de doelstelling van de voorzienbaarheid volgens het Hof niet op dezelfde wijze gewaarborgd, omdat de uitgevende instelling niet redelijkerwijs kan voorzien voor de gerechten van welke lidstaten zij zou kunnen worden opgeroepen. ${ }^{24}$

Op grond van het bovenstaande komt het Hof tot de volgende conclusie: ${ }^{25}$

'Hieruit volgt dat in het geval van een beursgenoteerde vennootschap als die welke in het hoofdgeding aan de orde is, enkel de gerechten van de lidstaten waar deze vennootschap met het oog op haar beursnotering heeft voldaan aan de wettelijke openbaarmakingsverplichtingen, bevoegd kunnen worden geacht uit hoofde van het intreden van de schade. Enkel in die lidstaten is het voor een dergelijke vennootschap namelijk redelijkerwijs voorzienbaar dat er een beleggingsmarkt bestaat en dat zij aansprakelijk wordt gesteld.'

\section{Twee ijkpunten in de rechtspraak van het Hof van Justitie: het belang van een goede rechtsbedeling en het belang van voorzienbaarheid}

De bijzondere bevoegdheidsregels uit hoofdstuk 2.2 van de Brussel I bis-Vo vinden hun grondslag in het belang van een goede rechtsbedeling en het belang van voorzienbaarheid. Deze twee grondslagen zijn terug te vinden in punt 16 van de Considerans van de Brussel I bis-Vo:

22. HvJ EU 12 mei 2021, C-709/19, ECLI:EU:C:2021:377 (VEB/BP), punt 32 .

23. HvJ EU 12 mei 2021, C-709/19, ECLI:EU:C:2021:377 (VEB/BP), punt 33 .

24. HvJ EU 12 mei 2021, C-709/19, ECLI:EU:C:2021:377 (VEB/BP), punt 34 .

25. HvJ EU 12 mei 2021, C-709/19, ECLI:EU:C:2021:377 (VEB/BP), punt 35 . 


\section{Maandblad}

'Naast de woonplaats van de verweerder moeten er alternatieve bevoegdheidsgronden mogelijk zijn, gebaseerd op de nauwe band tussen het gerecht en de vordering of de noodzaak een goede rechtsbedeling te vergemakkelijken. Het bestaan van een nauwe band moet zorgen voor rechtszekerheid en de mogelijkheid vermijden dat de verweerder wordt opgeroepen voor een gerecht van een lidstaat dat door hem redelijkerwijs niet voorzienbaar was. (...)'

Deze twee grondslagen fungeren in de rechtspraak van het Hof als ijkpunten bij de uitleg van art. 7 Brussel I bis-Vo. Het belang van de goede rechtsbedeling leidde het Hof in Bier tot de tweeledige uitleg van art. 7 punt 2 Brussel I bis-Vo. Het bieden van de keuze tussen de rechter van het Handlungsort en het Erfolgsort was gerechtvaardigd vanuit procesrechtelijk perspectief, nu beide aanknopingspunten een nuttig aanknopingspunt zouden kunnen vormen voor de bewijslevering en de procesvoering. ${ }^{26}$

Aan de andere kant hanteerde het Hof in Marinari de goede rechtsbedeling juist als ijkpunt om het Erfolgsort te kunnen beperken: het Erfolgsort omvat alleen de plaats waar de directe schade zich heeft voorgedaan met het oog op onder andere de doelmatige bewijsvorming: ${ }^{27}$

'Het zou immers kunnen, dat de na het oorspronkelijke schadebrengende feit gemaakte kosten en gederfde winsten op een andere plaats worden geconstateerd en dat derhalve, vanuit het oogpunt van doelmatige bewijsvoering, een dergelijk gerecht volstrekt misplaatst is.'

In andere gevallen lopen beide grondslagen als ijkpunten bij de uitleg van art. 7 Brussel I bis-Vo in elkaar over. Zo was in Universal Music de bevoegdheid van de Tsjechische rechter voorspelbaar, juist omdat de rechtsmacht van de Tsjechische rechter voor de hand lag vanuit een goede rechtsbedeling en een nuttige procesinrichting. ${ }^{28}$

Voor de lokalisering van het Erfolgsort bij claims voor zuivere vermogensschade op grond van prospectusaansprakelijkheid en misleidende mededelingen knoopt het Hof meer aan bij het tweede ijkpunt van het belang van voorzienbaarheid. Het Hof benadert dit ijkpunt niet alleen vanuit het perspectief van de gedaagde, maar plaatst dit begrip ook in de meer algemene context van het belang van de rechtsbescherming van zowel eiser als gedaagde. Vergelijk bijvoorbeeld de uitspraken van het Hof in Kronhofer/Maier, Kolassa/Barclays en Löber/Barclays.

Kronhofer/Maier:

26. HvJ EU 30 november 1976, C-21/76, ECLI:EU:C:1976:166 (Handelskwekerij Bier/Mines de Potasse d'Alsace), punten 11 en 17.

27. HvJ EU 19 september 1995, C-364/93, ECLI:EU:C:1995:289 (Marinari/Lloyds Bank), punt 20.

28. HvJ EU 16 juni 2016, C-12/15, ECLI:EU:C:2016:449 (Universal Music), punt 33.
'In een situatie als die in het hoofdgeding zou deze uitlegging de bepaling van het bevoegde gerecht doen afhangen van onzekere omstandigheden, zoals de plaats waar zich "het centrum van het vermogen" van het slachtoffer bevindt, en zou zij bijgevolg indruisen tegen de versterking van de rechtsbescherming van de in de Gemeenschap gevestigde personen, welke, door de eiser in staat te stellen om gemakkelijk te bepalen, welk gerecht hij kan aanzoeken, alsmede de verweerder om redelijkerwijs te voorzien, voor welk gerecht hij kan worden opgeroepen, een van de doelstellingen van het Executieverdrag vormt (...).' ${ }^{29}$ (curs. BS, DV \& FV)

Löber/Barclays (en, zeer vergelijkbaar, Kolassa/Barclays ${ }^{30}$ ):

'Dienaangaande moet met name eraan worden herinnerd dat de aanwijzing van de plaats van vestiging van de bank waarbij verzoekers bankrekening is geopend waarop de schade zich rechtstreeks voordoet, als de plaats van het intreden van de schade, strookt met het doel van verordening $n r$. 44/2001 de rechtsbescherming van in de Unie gevestigde personen te versterken - de verzoeker kan gemakkelijk bepalen welk gerecht hij kan aanzoeken en de verweerder kan redelijkerwijs voorzien voor welk gerecht hij kan worden opgeroepen - daar de emittent van een certificaat die zijn wettelijke verplichtingen met betrekking tot de prospectus niet nakomt erop moet rekenen, wanneer hij besluit de kennisgeving van de prospectus voor dat certificaat in andere lidstaten te doen, dat in die lidstaten wonende onvoldoende geïnformeerde marktdeelnemers in dat certificaat investeren en schade lijden (...). ${ }^{31}$ (curs. BS, DV \& FV)

Het belang van voorzienbaarheid heeft een tweeledige functie bij de uitleg van art. 7 punt 2 Brussel I bis-Vo. Enerzijds fungeert zij als de rechtvaardiging van deze bepaling, aan de hand waarvan daaraan 'effet utile' moet worden gegeven. Dit doet het Hof bijvoorbeeld in Kolassa/Barclays en Löber/Barclays (legitimerende functie). Anderzijds brengt de voorzienbaarheid een beperking aan op de reikwijdte van het Erfolgsort, om te voorkomen dat art. 7 punt 2 Brussel I bis-Vo leidt tot resultaten die niet meer stroken met het belang van rechtszekerheid (beperkende functie). Dit is bijvoorbeeld het geval in Kronhofer/Maier. In deze uitspraak werd de notie van voorzienbaarheid gehanteerd om een beperking aan te brengen op de mogelijkheid om het Erfolgsort van zuivere vermogensschade in een bepaalde plaats te kunnen lokaliseren. Het Hof hanteerde de notie van voorzienbaarheid op een vergelijkbare beperkende wijze in Verein für Konsumenteninformation/Volkswagen en Mittelbayerischer Verlag/SM, die betrekking hadden op zaakschade aan gekochte auto's met gestelde 'sjoemelsoftware' res-

29. HvJ EU 10 juni 2004, C-168/02, ECLI:EU:C:2004:364 (Kronhofer/ Maier), punt 20.

30. HvJ EU 28 januari 2015, C- 375/13, ECLI:EU:C:2015:37 (Kolassa/Barclays Bank), punt 56.

31. HvJ EU 12 september 2018, C-304/17, ECLI:EU:C:2018:701 (Löber/ Barclays Bank), punt 35 . 
pectievelijk een inbreuk op persoonlijkheidsrechten door een grievende uiting in een online publicatie. ${ }^{32}$ Deze tweeledige functie van de voorzienbaarheid is ook zichtbaar in VEB/BP, daar waar het Hof de casusposities van Löber/Barclays en VEB/BP contrasteert. ${ }^{33}$ De beperkende werking van voorzienbaarheid - daar waar een bepaald aanknopingspunt rechtsonzekerheid voor de gedaagde creëert - blijkt uit de overweging: ${ }^{34}$

'Zoals de advocaat-generaal in punt 29 van zijn conclusie heeft benadrukt, stellen de criteria die verband houden met de woonplaats en met de plaats waar de effectenbezitters een rekening aanhouden, de emitterende vennootschap in dat geval namelijk niet in staat om te anticiperen op de vaststelling van de internationale bevoegdheid van de gerechten waarvoor zij zou kunnen worden opgeroepen, hetgeen in strijd is met de in overweging 16 van verordening nr. 1215/2012 genoemde doelstelling die erin bestaat - teneinde het rechtszekerheidsbeginsel te waarborgen - de mogelijkheid te vermijden dat de verweerder wordt opgeroepen voor een gerecht van een lidstaat dat voor hem redelijkerwijs niet voorzienbaar was.'

In de uitspraken van het Hof over de lokalisering van schade komen aldus steeds het belang van een goede rechtsbedeling en het belang van voorzienbaarheid als twee ijkpunten terug. In de recentere rechtspraak over financial torts lijkt de nadruk verhoudingsgewijs meer op de rechtsbescherming door voorzienbaarheid te liggen.

\section{Algemeen geldende harde regel: geen 'indirecte' schade}

Een rechter kan alleen dan bevoegdheid ontlenen aan art. 7 punt 2 Brussel I bis-Vo indien de schade die ten grondslag is gelegd aan het beroep op die bepaling, is te kwalificeren als zogenoemde rechtstreekse schade. ${ }^{35}$ Rechtsmacht kan dus niet op deze bepaling worden gebaseerd indien geen sprake is van rechtstreeks schade maar van indirecte schade. Deze regel is een belangrijke en noodzakelijke inperking van een anders te ver uitdijende mogelijkheid om rechtsmacht te vestigen op de voet van art. 7 punt 2 Brussel I bis-Vo. Hij geldt voor alle typen van schade en dus niet alleen voor zuivere vermogensschade.

In de rechtspraak van het Hof kunnen twee gevalstypen worden onderscheiden waarin geen sprake is van rechtstreekse

32. HvJ EU 9 juli 2020, C-343/19, ECLI:EU:C:2020:534 (Verein für Konsumenteninformation/Volkswagen AG) en HvJ EU 17 juni 2021, C-800/19, ECLI:EU:C:2021:489 (Mittelbayerischer Verlag/SM).

33. HvJ EU 12 mei 2021, C-709/19, ECLI:EU:C:2021:377 (VEB/BP), punten 33-34.Vgl. ook Rank 2021, p. 78, die de uitspraak onderschrijft uit oogpunt van rechtszekerheid.

34. HvJ EU 12 mei 2021, C-709/19, ECLI:EU:C:2021:377 (VEB/BP), punt 34.

35. HvJ EU 11 januari 1990, C-220/88, ECLI:EU:C:1990:8 (Dumez France SA \& Tracoba/Hessische Landesbank). O.a. ook HvJ EU 12 mei 2021, C-709/19, ECLI:EU:C:2021:377 (VEB/BP), punt 27. schade. Het eerste gevalstype is dat waarin het handelen van de laedens schade toebrengt aan een gelaedeerde (die daardoor rechtstreeks wordt benadeeld), waardoor ook een ander schade ondervindt. Een goed voorbeeld van dit gevalstype is de zaak Dumez. ${ }^{36}$ In die zaak werd een in Duitsland gevestigde bank verweten ten onrechte een kredietovereenkomst met in Duitsland gevestigde vennootschappen te hebben opgezegd. Als gevolg daarvan waren de Duitse vennootschappen gefailleerd en leden de in Frankrijk gevestigde aandeelhouders van die vennootschappen schade. De Duitse bank werd vervolgens in Frankrijk gedaagd door de in Frankrijk gevestigde aandeelhouders. Het Hof oordeelde dat de gestelde schade slechts het indirecte gevolg is van de schade die oorspronkelijk is geleden door de Duitse vennootschappen. Onder 'de plaats waar het schadebrengende feit zich heeft voorgedaan' valt, aldus het Hof, alleen de plaats waar rechtstreeks schadelijke gevolgen intreden voor degene die er rechtstreeks door is gelaedeerd.

Het tweede gevalstype van indirecte schade is het geval waarin de gelaedeerde in een bepaalde lidstaat een bepaalde vorm van schade ondervindt en die reeds geleden schade ertoe leidt dat in een andere lidstaat nog een andere schade ontstaat. Een voorbeeld hiervan is de zaak Marinari. ${ }^{37}$ Nadat de in Italië woonachtige Marinari bij Lloyds Bank in het Verenigd Koninkrijk orderbriefjes had gedeponeerd, lichtten bankmedewerkers de politie in over het bestaan van die orderbriefjes en dat zij de herkomst daarvan als twijfelachtig beschouwden. Marinari werd hierop gearresteerd. Nadat hij in het Verenigd Koninkrijk van rechtsvervolging was ontslagen, daagde Marinari de bank voor de Italiaanse rechter en stelde onder meer dat hij in Italië schade had ondervonden aan zijn goede naam en verschillende contracten met hem waren verbroken. Het Hof oordeelde dat de 'plaats waar het schadebrengende feit zich heeft voorgedaan' niet zo ruim mag worden uitgelegd dat het iedere plaats omvat waar de schadelijke gevolgen voelbaar zijn van een feit dat reeds elders daadwerkelijk ingetreden schade heeft veroorzaakt. Deze uitdrukking ziet niet op de plaats waar de gelaedeerde stelt vermogensschade te hebben geleden als gevolg van een door hem geleden, in een andere lidstaat ingetreden aanvankelijke schade.

De afwijzing van indirecte schade als grondslag voor rechtsmacht is ingegeven door de wens te voorkomen dat de bijzondere regel van art. 7 Brussel I bis-Vo een zodanig ruim toepassingsbereik krijgt dat daarmee de hoofdregel van art. 4 Brussel I bis-Vo wordt uitgehold. Daarom moet de toepassing van die bijzondere regel beperkt blijven tot de gevallen waarin toepassing ervan gerechtvaardigd is vanwege een nauwe band tussen

36. HvJ EU 11 januari 1990, C-220/88, ECLI:EU:C:1990:8 (Dumez France SA \& Tracoba/Hessische Landesbank). Vgl. in de context van art. 4 punt 1 Rome II-Vo HvJ EU 10 december 2015, C-350/14, ECLI:EU:C: 2015:802 (Lazar/Allianz).

37. HvJ EU 19 september 1995, C-364/93, ECLI:EU:C:1995:289 (Marinari/Lloyds Bank). 
de aangezochte rechter en de zaak. ${ }^{38} \mathrm{Bij}$ indirecte schade zal van een dergelijke nauwe band veelal geen sprake zijn. De uitsluiting van indirecte schade als grond voor bevoegdheid is ook ingegeven door beduchtheid dat art. 7 punt 2 Brussel I bis-Vo leidt tot een verkapte aanvaarding van een forum actoris, waar die verordening nu juist afkerig tegenover staat. Verder wil het Hof vermijden dat rechtsmacht toekomt aan een veelvoud van rechters. ${ }^{39}$ Een veelvoud van bevoegde rechters is in het algemeen te vermijden, omdat dit gemakkelijk leidt tot forum shopping en tot het risico van onderling onverenigbare uitspraken.

In geval van letselschade of zaakschade zal het vaak relatief eenvoudig zijn om rechtstreekse schade van indirecte schade te onderscheiden, hoewel uit de rechtspraak blijkt dat ook in deze gevallen het onderscheid soms wat lastig kan zijn. ${ }^{40}$ De wijze waarop het Hof de vraag benadert of sprake is van rechtstreekse of van indirecte zuivere vermogensschade, kan worden verhelderd door een vergelijking te maken tussen de zaken Kronhofer/Maier en Löber. ${ }^{41}$

In eerstgenoemde zaak werd een in Oostenrijk woonachtige consument, Kronhofer, per telefoon door een in Duitsland gevestigde financiële dienstverlener, Protectas, ertoe verleid om te beleggen, evenwel zonder hem adequaat te waarschuwen voor de daaraan verbonden risico's. Om deze belegging te faciliteren werd van de in Oostenrijk aangehouden geldrekening van Kronhofer een bedrag overgemaakt naar een geldrekening bij Protectas in Duitsland. Vanaf deze rekening werd het bedrag vervolgens belegd in uiterst speculatieve optietransacties op de beurs in Londen. Kronhofer sprak de vennoten van Protectas niet voor de Duitse maar voor de Oostenrijkse rechter aan tot schadevergoeding. Hij stelde in Oostenrijk schade te hebben geleden omdat zijn vermogen als zodanig was verminderd en het zwaartepunt van zijn vermogen in Oostenrijk viel te lokaliseren. Onder verwijzing naar Marinari oordeelde het Hof echter dat onder 'plaats waar het schadebrengende feit zich heeft voorgedaan' niet valt de plaats waar de verzoeker woont of waar zich het 'centrum van zijn vermogen' bevindt op de enkele grond dat hij aldaar financiële schade heeft geleden, die voortvloeit uit het - in een andere lidstaat ingetreden en door hem geleden - verlies van onderdelen van zijn vermogen. Dit oordeel kan worden verklaard doordat met de overboeking vanaf de in Oostenrijk aangehouden rekening nog

38. HvJ EU 11 januari 1990, C-220/88, ECLI:EU:C:1990:8 (Dumez France SA \& Tracoba/Hessische Landesbank), punten 16 en 17 en HvJ EU 19 september 1995, C-364/93, ECLI:EU:C:1995:289 (Marinari/Lloyds Bank), punt 13.

39. HvJ EU 11 januari 1990, C-220/88, ECLI:EU:C:1990:8 (Dumez France SA \& Tracoba/Hessische Landesbank), punten 16, 18 en 19.

40. Vgl. bijv. HvJ EU 16 juli 2009, C-189/08, ECLI:EU:C:2009:475 (ZuidChemie/Philippo's Mineralenfabriek), HvJ EU 9 juli 2020, C-343/19, ECLI:EU:C:2020:534 (Verein für Konsumenteninformation/Volkswagen $\mathrm{AG}$ ) en HvJ EU 10 december 2015, C-350/14, ECLI:EU:C: 2015:802 (Lazar/Allianz).

41. HvJ EU 10 juni 2004, C-168/02, ECLI:EU:C:2004:364 (Kronhofer/ Maier e.a.) en HvJ EU 12 september 2018, C-304/17, ECLI:EU:C: 2018:701 (Löber/Barclays Bank). geen schade was ontstaan. Dat was pas het geval toen vanaf de in Duitsland aangehouden beleggingsrekening speculatieve en uiteindelijk verlieslatende beleggingen werden verricht.

In Löber/Barclays had het in Londen gevestigde Barclays effecten uitgegeven die op de secundaire markt waren verkocht aan consumenten in onder meer Oostenrijk, onder wie Löber. De effecten waren uitgegeven op basis van een Duits basisprospectus, dat ook in Oostenrijk was geregistreerd bij de bevoegde toezichthouder. Het in die certificaten belegde geld ging verloren. Löber sprak vervolgens Barclays aan voor de Oostenrijkse rechter met de stelling dat het prospectus in strijd met de in Oostenrijk geldende wettelijke regels onvolledig was. Anders dan Kronhofer had Löber zijn beleggingen gedaan op de Oostenrijkse secundaire markt bij een in Oostenrijk gevestigde bank en de bankrekeningen waarvandaan de betaling werd verricht, werden aangehouden in Oostenrijk: ${ }^{42}$

'Blijkens de verwijzingsbeslissing heeft Löber haar woonplaats namelijk in Oostenrijk en zijn alle betalingen betreffende de beleggingstransactie die in het hoofdgeding aan de orde is, via Oostenrijkse bankrekeningen verricht, te weten de persoonlijke bankrekening van Löber en de speciaal voor de uitvoering van deze transactie bestemde afwikkelingsrekeningen.'

Anders dan in Kronhofer/Maier ging het dus om schade die rechtstreeks in Oostenrijk intrad, zodat de regel van Marinari niet opging.

\section{Wanneer kan rechtsmacht op grond van Erfolgsort worden aanvaard?}

\subsection{Twee elementen in de analyse}

Hoewel de rechtspraak van het Hof dit niet altijd duidelijk doet, kunnen naar onze mening vanuit conceptueel oogpunt twee elementen worden onderscheiden in de analyse of een rechter rechtsmacht kan ontlenen aan art. 7 punt 2 Brussel I bis-Vo omdat in zijn rechtsgebied schade is ingetreden: ${ }^{43}$

42. HvJ EU 12 september 2018, C-304/17, ECLI:EU:C:2018:701 (Löber/ Barclays Bank), punt 32 .

43. In zijn bespreking van Verein für Konsumenteninformation/Volkswagen in NIPR 2020, p. 445 en 446, lijkt Ten Wolde deze twee elementen ook van elkaar te onderscheiden. Ook bij Van Bochove tekenen zich deze twee elementen af: Van Bochove 2021, par. 7-8. Vgl. evenwel de benadering in concl. A-G Campos Sanchéz-Bordona vóór dit arrest, ECLI:EU:C:2020:253, onder 70, die maant tot voorzichtigheid bij het voor alle vorderingen wegens zuivere vermogensschade hanteren van een werkwijze waarbij als onderdeel van een alomvattende beoordeling van de specifieke omstandigheden van de zaak eerst de plaats moet worden vastgesteld waar de schade is ingetreden en vervolgens moet worden bepaald of die plaats (al dan niet) geschikt is als criterium voor de toekenning van rechterlijke bevoegdheid. De twee-elementenbenadering probeert structuur en helderheid te brengen in wat de tweede auteur van het onderhavige artikel eerder omschreef als de 'helikopter'-benadering van het Hof van Justitie (D.J. Verheij, Credit Rating Agency Liability in Europe. Rating the Combination of EU and National Law in Rights of Redress, Den Haag: Eleven International Publishing 2020, p. 167). 
- Het eerste element betreft de feitelijke lokalisatie dan wel allocatie van de schade: gezocht wordt naar aanknopingspunten die de schade aan de plaats van de aangezochte rechter koppelen.

- Het tweede element betreft de rechtvaardiging van de rechtsmacht: gezocht wordt naar feiten en omstandigheden die rechtsmacht van de aangezochte rechter rechtvaardigen.

Daar waar het eerste element een meer feitelijk karakter heeft, is het tweede element meer juridisch van aard. Het eerste element houdt in dat de schade die wordt ingeroepen als grondslag voor het beroep op art. 7 punt 2 Brussel I bis-Vo, moet aangrijpen in het rechtsgebied van de rechter. Bij gebreke daarvan kan rechtsmacht niet worden gebaseerd op art. 7 punt 2 Brussel I bis-Vo, zelfs indien de betreffende rechter op zich goed gepositioneerd zou zijn om de zaak te beoordelen (als een soort forum conveniens). ${ }^{44}$ Dit element houdt in zoverre verband met de beoordeling of sprake is van rechtstreekse schade of niet, dat ook die beoordeling moet worden verricht aan de hand van de schade die de eiser aan het beroep op art. 7 punt 2 Brussel I bis-Vo ten grondslag heeft gelegd.

Bij het tweede element gaat het erom of rechtsmacht gerechtvaardigd is. Daarbij zijn de hiervoor besproken grondslagen van art. 7 punt 2 Brussel I bis-Vo de ijkpunten, in het licht waarvan de omstandigheden van het geval worden gewaardeerd. Is de uitkomst van deze analyse negatief, dan kan niet worden gesproken van een rechtens - voor de toepassing van art. 7 punt 2 Brussel I bis-Vo - relevant Erfolgsort waarop de aangezochte rechter zijn rechtsmacht kan baseren. ${ }^{45}$ Juist bij zaken die zuivere vermogensschade betreffen, is dit tweede element van cruciaal belang. Dit belet immers dat rechters rechtsmacht aannemen ten aanzien van vorderingen waarmee zij geen nauwe band hebben.

Deze benadering blijkt bijvoorbeeld uit het arrest Verein für Konsumenteninformation/Volkswagen. ${ }^{46}$ In die zaak ging het om schade die kopers van auto's hadden geleden als gevolg van verlies van waarde van hun gekochte auto's doordat daarin software bleek te zijn geïnstalleerd waarmee emissiegegevens zouden zijn gemanipuleerd. Het Hof constateerde dat kopers rechtstreekse schade hebben ondervonden bij de aankoop van de auto's. Daarbij ging het Hof blijkens het antwoord op de prejudiciële vraag impliciet ervan uit dat die schade intreedt waar de auto's zijn gekocht. ${ }^{47}$ Vervolgens overwoog het Hof dat een dergelijke uitleg van art. 7 punt 2 Brussel I bis-Vo in overeenstemming is met de doelstelling van voorspelbaarheid. Een autofabrikant die zich schuldig maakt aan manipulaties van in andere lidstaten in de handel gebrachte auto's, moet volgens het Hof verwachten dat schade zich voordoet waar een betrokken auto wordt gekocht. Kortom, het Hof heeft zijn analyse niet alleen beperkt tot uitsluitend de feitelijke constatering of schade zich al dan niet voordoet in een bepaalde lidstaat. Het heeft zich ook de vraag gesteld of het gelet op de grondslagen van art. 7 punt 2 Brussel I bis-Vo gerechtvaardigd is dat de rechter van die lidstaat rechtsmacht toekomt.

\subsection{Element 1: lokalisatie/allocatie van de schade}

Het eerste element betreft de feitelijke lokalisatie dan wel allocatie van de schade: welke feitelijke aanknopingspunten koppelen de schade aan de plaats van de aangezochte rechter? In zijn rechtspraak duidt het Hof de plaats van het intreden van de schade doorgaans aan als de plaats waar de gevolgen van het schadeveroorzakende feit intreden, dat wil zeggen de plaats waar de teweeggebrachte schade zich concreet voordoet. ${ }^{48}$

Onzes inziens is de benadering van het Hof welbeschouwd ruimer dan het lokaliseren (in strikte zin) van de plaats waar de teweeggebrachte schade zich concreet voordoet. Materiële schade kan zich inderdaad concreet voordoen en de plaats waar dat het geval is, kan veelal eenvoudigweg worden vastgesteld. Dat is bij andere soorten schade echter niet noodzakelijkerwijs het geval. Het voorbeeld van zuivere vermogensschade veroorzaakt door de waardedaling van effecten is hiervan een voor de hand liggend voorbeeld. De problematiek is echter breder: denk bijvoorbeeld aan schade die is veroorzaakt door de waardevermindering van materiële goederen als aan de orde in de zaak Verein für Konsumenteninformation/Volkswagen. ${ }^{49}$ Naar hun aard kennen deze typen schade geen fysieke verschijningsvorm, zodat die zich welbeschouwd niet werkelijk ergens concreet kunnen voordoen. Veeleer gaat het hier erom de schade bij een bepaalde rechter onder te brengen op basis van bepaalde aanknopingspunten. Het eerste element biedt de noodzakelijke ruimte om verschillende typen schade vanuit dezelfde algemene principes te 'lokaliseren'.

Een voorbeeld uit de rechtspraak waaruit blijkt dat de benadering van het Hof welbeschouwd neerkomt op een soort allocatie van schade op basis van aanknopingsfactoren, is zijn rechtspraak volgens welke schade zich kan voordoen op een bankrekening. ${ }^{50}$ Giraal geld en effecten zijn abstracties en de rekeningen waarop zij worden geadministreerd, zijn niet meer dan een administratief instrument om een recht met betrek-

44. Vgl. in andere bewoordingen Ten Wolde 2020, p. 271.

45. Strikt genomen doet zich wellicht schade voor (in enig opzicht), maar die is dan in het licht van de grondslagen van art. 7 punt 2 Brussel I bis-Vo onvoldoende om rechtsmacht van de aangezochte rechter te rechtvaardigen. Vgl. Ten Wolde 2020, p. 253.

46. HvJ EU 9 juli 2020, C-343/91, ECLI:EU:C:2020:534 (Verein für Konsumenteninformation/Volkswagen AG). Het belang van de ratio van art. 7 punt 2 Brussel I bis-Vo als toetssteen komt ook naar voren in Van Bochove 2021, par. 7.

47. Punten 33-35 en het antwoord op de prejudiciële vraag.

48. HvJ EU 16 juli 2009, C-189/08, ECLI:EU:C:2009:475 (Zuidchemie).

49. HvJ EU 9 juli 2020, C-343/91, ECLI:EU:C:2020:534 (Verein für Konsumenteninformation/Volkswagen AG).

50. Vgl. concl. A-G Campos Sanchéz-Bordona vóór VEB/BP, ECLI:EU:C: 2020:1056, onder 24 e.v., die een geografische plaatsbepaling van zuivere vermogensschade met betrekking tot aandelen op een beleggingsrekening bestempelt als 'figuurlijk of fictief. 
king tot een hoeveelheid geld of effecten weer te geven. ${ }^{51}$ De economische waarde van effecten wordt als zodanig niet weergegeven in een beleggingsrekening en het verloop van een beleggingsrekening wordt niet als zodanig beïnvloed door de ontwikkeling van die waarde. Wanneer het Hof (en rechters in de verschillende lidstaten) de uitdrukking hanteert dat schade zich voordoet op een bankrekening, gaat het welbeschouwd erom dat een recht dat naar zijn aard geen fysieke manifestatie kent, maar waaraan toch schade is ontstaan, voor de toepassing van art. 7 punt 2 Brussel I bis-Vo wordt gelokaliseerd in een bepaald rechtsgebied. Daartoe wordt dan de bankrekening gehanteerd als aanknopingsfactor. Het geld of de effecten kunnen dan aan de hand daarvan worden gelokaliseerd in het rechtsgebied waarin de rekening wordt aangehouden. Voor de goede orde: een andere vraag is of de aanwezigheid van een bankrekening waarop zich schade voordoet in een lidstaat, voldoende is om rechtsmacht van de rechter van die lidstaat te kunnen vestigen. Dat is het tweede element in de analyse.

Waar en wanneer schade intreedt, is afhankelijk van de aard van de onrechtmatige gedraging en de schade. Kijken we naar zuivere vermogensschade in het algemeen, dan heeft het Hof voor wat betreft het eerste element in de analyse verschillende benaderingswijzen gehanteerd waarmee dergelijke schade aan meerdere momenten en plaatsen is gekoppeld. Afhankelijk van de omstandigheden van het geval kan in het voetspoor van Kolassa/Barclays en Löber/Barclays beleggingsschade zich voordoen op een bankrekening ${ }^{52}$ en kan die rekening worden gelokaliseerd op de plaats waar zij wordt aangehouden, kan beleggingsschade in het voetspoor van $\mathrm{VEB} / \mathrm{BP}^{53}$ intreden op de plaats waar met het oog op een beursnotering is of had moeten worden voldaan aan wettelijke openbaarmakingsverplichtingen, of kan naar analogie van Universal Music ${ }^{54}$ schade aan een vermogen worden gezegd te zijn ontstaan doordat een contractuele verbintenis is ontstaan die leidt tot vermindering van het vermogen, en kan die verbintenis worden gelokaliseerd waar het betreffende contract is gesloten. In geval van beleggingsschade als gevolg van een schending van één of meer informatieplichten zou naar analogie van Verein für Konsumenteninformation/Volkswagen ${ }^{55}$ ook denkbaar zijn dat schade geacht wordt in te treden met de aankoop van effecten die in werkelijkheid minder waard zijn dan de betaalde koopprijs, omdat de schending van de informatieplicht(en) heeft geleid tot een kunstmatig hoge prijs.

51. Vgl. ook M. Haentjens \& D.J. Verheij, Finding Nemo: Locating Financial Losses after Kolassa/Barclays Bank and Profit, Journal of International Banking Law \& Regulation 2016, afl. 6, p. 346-358.

52. De tweede auteur van het onderhavige artikel heeft eerder verdedigd dat het in Kolassa/Barclays specifiek ging om de beleggingsrekening, Haentjens \& Verheij 2016, p. 346-358.

53. Punt 35.

54. Punten 30-32.

55. HvJ EU 9 juli 2020, C-343/19, ECLI:EU:C:2020:534 (Verein für Konsumenteninformation/Volkswagen AG).
Het Hof is helaas niet altijd duidelijk en consistent in zijn benadering bij de beantwoording van de vraag wanneer en waar schade ontstaat. ${ }^{56}$ De benadering in Kolassa/Barclays en Löber/Barclays, waarbij als schade als gevolg van een schending van een informatieplicht ${ }^{57}$ werd aangemerkt de vermindering van een saldo van een bankrekening, is ons inziens vanuit conceptueel oogpunt lastig te verenigen met de benadering in Universal Music. In die uitspraak merkt het Hof de verbintenis tot betaling van een te hoge koopprijs aan als schade en de betaling van een schikkingsbedrag vanaf een rekening als een gebeurtenis die op zich geen schade heeft doen ontstaan. Dat een aankoop al (directe) schade kan doen ontstaan, is in Verein für Konsumenteninformation/Volkswagen bevestigd. Trekt men deze gedachte consequent door ten aanzien van prospectusaansprakelijkheid, dan rijst de vraag waarom de schade in dat geval toch ontstaat met de vermindering van het saldo op een bankrekening in plaats van met de door de misleiding tot stand gebrachte aankoop. ${ }^{58}$ Een keuze voor dit laatste zou ook ermee stroken dat de regel dat een prospectus niet misleidend mag zijn, juist ertoe strekt te bewerkstelligen dat een belegger die overweegt de effecten te kopen goed geïnformeerd een aankoopbeslissing kan nemen.

De benadering van het Hof doet dus niet geheel consistent aan, wat onverlet laat dat de resultaten van de redenering van het Hof te billijken zijn. Wellicht is deze inconsistentie te verklaren doordat de rechtspraak van het Hof op dit punt wat gekleurd is geraakt door de procesvoering in feitelijke instanties en de specifieke soort schade. In Kolassa/Barclays, Löber/ Barclays en VEB/BP was, net als in Kronhofer/Maier, door de eiser gesteld dat schade was ingetreden op zijn geld- of beleggingsrekening, wat verklaarbaar is omdat daarmee de eiser in zijn eigen land zou kunnen procederen. Dit verklaart mogelijk waarom het Hof zijn antwoord in die zaken zo heeft toegespitst op het zich voordoen van schade op een geld- of beleggingsrekening in plaats van op het intreden van schade door het verrichten van een beleggingstransactie. De zaak VEB/BP is wellicht case in point: de Hoge Raad had in zijn vraagstelling als uitgangspunt genomen dat de schade rechtstreeks was ingetreden op de beleggingsrekeningen die in Nederland werden aangehouden, het Hof is daarom hiervan uitgegaan en heeft zijn antwoord hierop toegespitst (zie ook hiervoor par. 2.1 en 2.2 .

Evenwel moet deze inconsistentie ons inziens ook weer niet worden overtrokken. Blijkens Löber/Barclays is het Hof zich ervan bewust dat het niet geheel zuiver is om een vermindering van (het saldo op) een bankrekening aan te merken als schade voor de toepassing van art. 7 punt 2 Brussel I bis-Vo. Het Hof overwoog in punten 31-33 immers expliciet dat in de

56. Zie hierover ook o.a. Van Bochove 2021, par. 4. Vgl. B. Hess, Reforming the Brussels Ibis Regulation: Perspectives and Prospects, MPILux Research Paper Series 2021/4, p. 9.

57. Waaronder wij nu kortheidshalve ook verstaan de verplichting een nietmisleidend prospectus te publiceren.

58. Vgl. concl. A-G Bobek vóór Löber/Barclays, ECLI:EU:C:2018:310, onder 68 e.v. 
voorliggende zaak specifieke omstandigheden tezamen bijdragen tot toekenning van bevoegdheid aan de Oostenrijkse rechter:

- Löber heeft haar woonplaats in Oostenrijk.

- Alle betalingen betreffende de beleggingstransactie zijn via Oostenrijkse bankrekeningen verricht.

- Löber heeft in het kader van die transactie alleen met Oostenrijkse banken gehandeld.

- Zij heeft de certificaten op de Oostenrijkse secundaire markt verkregen.

- De haar verstrekte informatie over de certificaten bestaat uit de informatie in het prospectus.

- Zij heeft zich in Oostenrijk op basis van deze informatie ertoe verbonden om te beleggen, welke verbintenis definitief op haar vermogen drukte.

Welbeschouwd zien met name de laatste drie bijkomende omstandigheden erop dat het in Oostenrijk beschikbaar stellen van een misleidend prospectus ertoe heeft geleid dat in Oostenrijk op basis van dat prospectus transacties zijn verricht die hebben geresulteerd in schade. ${ }^{59}$ Legt men de nadruk op déze omstandigheden in plaats van op de eerste drie omstandigheden, dan is de uitspraak in Löber/Barclays (net als die in Kolassa/Barclays) meer in lijn met de benadering van het Hof in Universal Music en Verein für Konsumenteninformation/ Volkswagen. ${ }^{60}$

Ook de uitspraak VEB/BP kan in deze sleutel worden geplaatst. In punten 32 en 33 verwijst het Hof weliswaar naar Löber/Barclays en Kolassa/Barclays, maar contrasteert in punt 34 die twee zaken met de zaak VEB/BP. Hierop volgt het oordeel dat de doelstelling van voorzienbaarheid niet op dezelfde wijze wordt gewaarborgd wanneer in de lidstaat waar de beleggingsrekening wordt aangehouden die is gebruikt voor de aankoop van effecten die in een andere staat aan de beurs zijn genoteerd, geen wettelijke openbaarmakingsverplichtingen gelden voor de emittent van die effecten. In punt 35 vervolgt het Hof zijn gedachtegang met de overweging dat in het geval van een beursgenoteerde vennootschap uitsluitend de gerechten van de lidstaten waar deze vennootschap met het oog op haar beursnotering heeft voldaan aan de wettelijke openbaarmakingsverplichtingen, bevoegd kunnen worden geacht uit hoofde van het intreden van de schade. Alleen in die lidstaten is het voor een dergelijke vennootschap namelijk redelijkerwijs voorzienbaar dat er een beleggingsmarkt bestaat en dat zij aansprakelijk wordt gesteld. De relevantie die het Hof toekent aan de plaats waar met het oog op de beursnotering is voldaan aan de wettelijke openbaarmakingsverplichtingen, kan worden verklaard doordat voor de hand ligt dat op die plaats transacties zullen worden verricht op basis van de aldaar verstrekte informatie, en dat die transacties schade zullen veroorzaken.

59. Vgl. concl. A-G Campos Sanchéz-Bordona vóór Verein für Konsumenteninformation/Volkswagen AG, ECLI:EU:C:2020:253, onder 67 e.v.

60. Uit de directe bewoording van Löber/Barclays blijkt overigens niet welk aanknopingspunt uiteindelijk de doorslag gaf voor het Hof van Justitie.

\subsection{Element 2: rechtvaardiging van rechtsmacht}

Het tweede element betreft de rechtvaardiging van de rechtsmacht: is de rechtsmacht van de aangezochte rechter onder de gegeven omstandigheden gerechtvaardigd? Deze vraag moet worden bezien tegen de achtergrond van de hiervoor besproken grondslagen van art. 7 punt 2 Brussel I bis-Vo die de ijkpunten vormen, in het licht waarvan de omstandigheden van het geval worden gewaardeerd: het belang van een goede rechtsbedeling en het belang van voorzienbaarheid. In diverse uitspraken valt op dat het Hof die grondslagen als ijkpunten gebruikt om het resultaat van de toepassing van art. 7 punt 2 Brussel I bis-Vo bij te sturen. Het is deze bijsturing die maakt dat het uiteindelijke resultaat van de uitspraken van het Hof aanvaardbaar is.

Deze benadering is bijvoorbeeld terug te zien in de rechtspraak van het Hof waarin de plaats van de bankrekening als aanknopingspunt aan de orde komt. In Universal Music oordeelde het Hof dat de plaats van de bankrekening waarop een financieel verlies direct is ingetreden niet als Erfolgsort kan worden aangemerkt bij gebrek aan andere relevante aanknopingspunten: ${ }^{61}$

'Artikel 5, punt 3, van verordening (EG) nr. 44/2001 van de Raad van 22 december 2000 betreffende de rechterlijke bevoegdheid, de erkenning en de tenuitvoerlegging van beslissingen in burgerlijke en handelszaken, moet aldus worden uitgelegd dat, in een situatie als aan de orde in het hoofdgeding, als "plaats waar het schadebrengende feit zich heeft voorgedaan” niet kan worden aangemerkt, bij gebreke van andere aanknopingspunten, de plaats in een lidstaat waar de schade is ingetreden wanneer die schade uitsluitend bestaat in een financieel verlies dat rechtstreeks intreedt op de bankrekening van de verzoeker en het rechtstreekse gevolg is van een onrechtmatige gedraging die zich heeft voorgedaan in een andere lidstaat.'

Het Hof motiveerde deze beslissing met een beroep op de voorzienbaarheid, nu de plaats van de bankrekening geen betrouwbaar aanknopingspunt vormt. ${ }^{62}$ Dat wekt ook geen verbazing, aangezien de plaats waar de rekening zich bevindt veelal zal overeenkomen met de woon- of verblijfplaats van de gelaedeerde en die plaats kan worden gemanipuleerd. Ook is de plaats waar een rekening wordt aangehouden voor de laedens een onvoorzienbaar gegeven dat hem geen enkele indicatie geeft waar hij kan worden gedaagd. In de uitspraken Kolassa/Barclays en Löber/Barclays waren het dan ook telkens de bijkomstige omstandigheden die rechtvaardigden dat de rechter van de plaats waar de bankrekening waarop de schade zich had voorgedaan bevoegd was. Met het oog op de voorzienbaarheid is met name van betekenis dat het Hof overwoog dat Barclays een prospectus had genotificeerd bij de Oostenrijkse toe-

$\overline{\text { 61. HvJ EU } 16}$ juni 2016, C-12/15, ECLI:EU:C:2016:449 (Universal Music).

62. HvJ EU 16 juni 2016, C-12/15, ECLI:EU:C:2016:449 (Universal Music), punt 38 . 


\section{Maandblad}

zichthouder en dat de emittent van effecten die niet voldoet aan zijn wettelijke verplichtingen met betrekking tot het prospectus, wanneer hij besluit de kennisgeving van dat prospectus in andere lidstaten te doen, erop moet rekenen dat in die lidstaten wonende onvoldoende geïnformeerde marktdeelnemers in die effecten zullen investeren en schade lijden. ${ }^{63}$

Een 'bijsturing' zoals bedoeld vindt niet alleen plaats bij zuivere vermogensschade, maar ook bij andere schadetypen. Als voorbeeld valt te wijzen op de rechtspraak over inbreuk op persoonlijkheidsrechten door onrechtmatige internetpublicaties. Het Hof heeft in eDate Advertising e.a. ${ }^{64}$ als regel geformuleerd dat een slachtoffer van een dergelijke publicatie de vordering kan instellen waar hij het centrum van zijn belangen heeft. Aan deze regel legde het Hof ten grondslag dat hij strookt met de voorzienbaarheid vanuit het oogpunt van de verweerder, aangezien de uitgever van inbreukmakende content op het moment waarop hij deze op internet plaatst, de centra van de belangen van de bij de content betrokken personen kan kennen. Daarbij wees het Hof er ook op dat de verzoeker gemakkelijk kan bepalen welk gerecht hij kan aanzoeken. Deze regel geldt echter uitsluitend voor situaties waarin op internet geplaatste content rechtstreeks is gericht op de personen die beweerdelijk slachtoffer zijn van schending van hun persoonlijkheidsrechten, aangezien zij daarin met naam worden genoemd. Anders zou afbreuk worden gedaan aan de voorspelbaarheid en aan de rechtszekerheid. Op het moment dat de uitgever content plaatst, kan hij redelijkerwijs geen weet hebben van de centra van de belangen van personen op wie deze content geenszins is gericht.

\section{Enkele algemene lessen uit VEB/BP}

Met VEB/BP heeft het Hof een nieuwe loot toegevoegd aan zijn rechtspraak over zuivere vermogensschade. Het resultaat van deze uitspraak - namelijk dat een aangezochte rechter niet enkel op basis van de plaats van een beleggingsrekening rechtsmacht kan aannemen - verbaast niet. Dit is conform de hoofdregel die het Hof al had geformuleerd in Universal Music en goed verklaarbaar vanuit de ratio achter art. 7 punt 2 Brussel I bis-Vo. ${ }^{65}$

Daarnaast lijkt het Hof een regel te hebben geformuleerd voor het bepalen van het Erfolgsort voor het specifieke gevalstype waarin een vordering jegens een beursvennootschap is ingesteld die is gebaseerd op ongerichte onjuiste, onvolledige of misleidende mededelingen: ${ }^{66}$

63. HvJ EU 12 september 2018, C-304/17, ECLI:EU:C:2018:701 (Löber/ Barclays Bank), punten 33 en 35 en HvJ EU 28 januari 2015, C- 375/13, ECLI:EU:C:2015:37 (Kolassa/Barclays Bank), punt 56.

64. HvJ EU 25 oktober 2011, C- 509/09 en C- 161/10, ECLI:EU:C: 2011:685 (eDate Advertising e.a.), HvJ EU 17 oktober 2017, C- 194/16, ECLI:EU:C:2017:766 (Bolagsupplysningen en Ilsjan) en HvJ EU 17 juni 2021, C-800/19, ECLI:EU:C:2021:489 (Mittelbayerischer Ver$\operatorname{lag} / \mathrm{SM})$.

65. Vgl. ook de voorspelling van Ten Wolde in Ten Wolde 2020, p. 274-275.

66. Punt 35, vgl. dictum. Maar deze overweging wordt ook anders gelezen, vgl. Van Bochove \& Haentjens 2021.
'[E]nkel de gerechten van de lidstaten waar deze vennootschap met het oog op haar beursnotering heeft voldaan aan de wettelijke openbaarmakingsverplichtingen, [kunnen] bevoegd (...) worden geacht uit hoofde van het intreden van de schade. Enkel in die lidstaten is het voor een dergelijke vennootschap namelijk redelijkerwijs voorzienbaar dat er een beleggingsmarkt bestaat en dat zij aansprakelijk wordt gesteld.' (curs. BS, DV \& FV)

Dit lijkt ons de hoofdregel, waarvan onder bijzondere omstandigheden allicht een afwijking mogelijk zal zijn. Van belang is dat deze (hoofd)regel uitgaat van de premisse dat met het oog op een beursnotering aan een openbaarmakingsverplichting is voldaan. De reikwijdte van deze regel is wat onduidelijk. Zo blijkt uit de uitspraak niet of de regel ziet op alle informatie die door de vennootschap openbaar wordt gemaakt of alleen op die informatie die specifiek met het oog op een beursnotering krachtens een daartoe geldende verplichting openbaar is gemaakt. Niet alle door een vennootschap geopenbaarde informatie zal in laatstgenoemde categorie vallen.

Toepassing van de (hoofd)regel leidt waarschijnlijk ertoe dat Handlungsort en Erfolgsort territoriaal gezien al snel zullen samenvallen. ${ }^{67}$ De plaats waar de vennootschap aan haar openbaarmakingsplicht heeft voldaan, zal onder omstandigheden ook als Handlungsort te duiden zijn. Op zich is dit niets vreemds en een dergelijke samenval is, ook buiten de context van zuivere vermogensschade, goed mogelijk. Bier gaf immers een regel voor gevallen waarin de plaats waar zich een schadetoebrengend feit heeft voorgedaan en de plaats waar de schade is ontstaan niet samenvallen, maar dat laat onverlet dat deze plaatsen wel kunnen samenvallen. ${ }^{68}$ Te denken valt alleen al aan het veelgebruikte voorbeeld van een auto-ongeluk, waarbij de handeling onmiddellijk ook de (rechtstreekse) schade doet intreden.

Opvallend in de uitspraak VEB/BP is verder dat het Hof met de zojuist bedoelde (hoofd)regel voorbijgaat aan schade die zich zou voordoen op de beleggingsrekening (voor wat betreft het eerste element, zie hierover ook par. 5.2). Praktisch gezien zou dit geen verschil maken omdat het Hof kan bijsturen aan de hand van de ijkpunten (het tweede element), maar conceptueel gezien lijkt de schadebenadering van het Hof toe te groeien naar de plaats waar de transacties zullen worden verricht op basis van de aldaar verstrekte informatie. Wellicht is dit een teken aan de wand dat het Hof zijn benaderingswijze op dit punt stilletjes bijstelt.

De vraag kan worden gesteld hoe moet worden omgegaan met een dual listing, en in het bijzonder: moet de gelaedeerde in

67. Zie ook M. Lehmann, CJEU in Effectenbezitters v. BP: Jurisdiction for Collective Actions Based on Incorrect Investor Information, EAPIL Blog 21 mei 2021, https://eapil.org/2021/05/21/cjeu-in-effectenbezitters-vbp-jurisdiction-for-collective-actions-based-on-incorrect-investorinformation/ en Franken 2021.

68. Vgl. HvJ EU 30 november 1976, C-21/76, ECLI:EU:C:1976:166 (Handelskwekerij Bier/Mines de Potasse d'Alsace), par. 24. 


\section{Maandblad}

dat geval stellen dat hij zijn schade heeft geleden door te handelen op de beurs in de lidstaat waarvan hij de rechter aanzoekt, of mag hij gaan forum shoppen? Wij begrijpen de (hoofd)regel van VEB/BP aldus dat hij is ingegeven door de gedachte dat indien een vennootschap met het oog op een beursnotering in een bepaalde lidstaat informatie verstrekt die bekend raakt op de beleggingsmarkt in die lidstaat, zij redelijkerwijs kan voorzien dat op basis van die informatie op die beleggingsmarkt zal worden gehandeld en zij dus schade veroorzaakt indien de verstrekte informatie onjuist, onvolledig of misleidend is. Art. 7 punt 2 Brussel I bis-Vo vergt dat zich schade voordoet in de lidstaat waarvan de rechter wordt aangezocht (element 1, zie par. 5.2), en daarvoor volstaat niet dat de rechtsmacht van de aangezochte rechter voorzienbaar is. Daarenboven staat het Hof blijkens zijn rechtspraak niet positief tegenover forum shopping. Wij houden het daarom erop dat de gelaedeerde niet vrijelijk mag forum shoppen, maar zijn vordering moet brengen bij de rechter van de plaats waar de vennootschap informatie openbaar heeft gemaakt en waar de gelaedeerde op de aldaar gevestigde beleggingsmarkt transacties heeft verricht (waarbij dit laatste aspect dus doorslaggevend zal zijn, omdat er twee verschillende loci zijn waar de vennootschap de informatie openbaar heeft gemaakt). ${ }^{69}$

De regel uit VEB/BP lijkt ons alleen van toepassing in dat specifieke gevalstype. Dat dit het geval is, blijkt al uit het feit dat het Hof deze zaak duidelijk differentieert van Löber/Barclays over prospectusaansprakelijkheid. De regel laat zich bovendien niet zomaar toepassen op andere gevalstypen, zoals gevallen waarin informatie met betrekking tot een vennootschap openbaar is gemaakt indien die informatie afkomstig is van een derde die verantwoordelijk is voor die informatie en deze niet juist, onvolledig of misleidend is. Te denken valt bijvoorbeeld aan de aansprakelijkheid van kredietbeoordelaars en accountants die een jaarrekening controleren. Voor dergelijke gevallen geldt immers niet dat zij een specifieke wettelijke openbaarmakingsverplichting hebben. Belangrijk is tevens dat toepassing van VEB/BP in dergelijke gevallen ook niet strookt met de ijkpunten uit de rechtspraak van het Hof. Zo wijst het Hof in VEB/BP in het kader van de voorzienbaarheid expliciet op de beursnotering en de aanwezigheid van een beleggingsmarkt. Deze aanknopingspunten gelden voor een beursgenoteerde vennootschap en niet voor een kredietbeoordelaar of een controlerend accountant. In die gevallen moet worden teruggevallen op de twee-elementenbenadering, die er op grond van de voorzienbaarheid in deze gevallen goed toe zou kunnen leiden dat een rechtens relevant Erfolgsort niet bestaat.

\section{Afsluiting}

De rechtspraak van het Hof sinds Bier over het Erfolgsort laat zien dat het Hof laveert tussen enerzijds zijn wens recht te doen aan het nuttig effect van art. 7 punt 2 Brussel I bis-Vo en anderzijds zijn wens de goede rechtsbedeling en de voorzienbaarheid voor de gedaagde van de plaats waar hij kan worden gedaagd (en, daarmee, de rechtszekerheid) te bewaken. Dat levert een spanningsveld op. $\mathrm{Nu}$ onze verwachting is dat het Hof bij zuivere vermogensschade aan het Erfolgsort zal blijven vasthouden, hebben wij getracht de benadering van het Hof te conceptualiseren aan de hand van de twee-elementenbenadering. Wij zien dat zich een lijn in de rechtspraak aftekent, waarbij het Hof niet alleen op basis van de feiten toetst of schade aangrijpt in een lidstaat (het eerste element), maar nu juist ook de grondslagen van art. 7 punt 2 Brussel I bis-Vo als ijkpunten gebruikt om (onder meer) onvoorzienbare en daarom onaanvaardbare resultaten te voorkomen (het tweede element). Ook het onderhavige arrest VEB/BP kan in dit kader worden geplaatst.

69. Anders: Franken 2021 